International Journal of Life Sciences
Available online at www.sciencescholar.us
Vol. 5 No. 3, December 2021, pages: 164-170
e-ISSN: 2550-6986, p-ISSN: 2550-6994
https://doi.org/10.53730/ijls.v5n3.1722

\title{
Patient Dose Monitoring Using Exposure Index Against Body Mass Index Level on Chest X-ray Examination
}

\begin{abstract}
(1) crossuatik
Ni Komang Tri Suandayani a , Gusti Ngurah Sutapa b , I Gde Antha Kasmawan c

Manuscript submitted: 09 August 2021, Manuscript revised: 18 September 2021, Accepted for publication: 27 October 2021

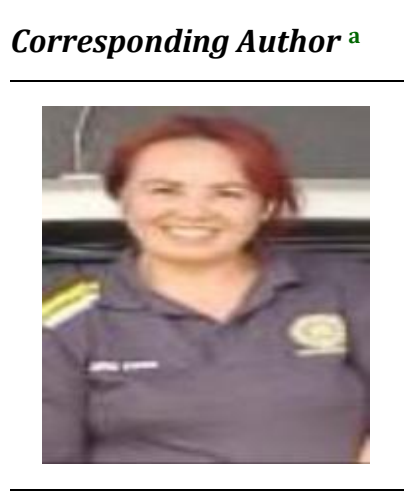

Keywords

body mass index;

dosage monitoring;

exposure index;

radiographic;

$X$-ray examination;

\section{Abstract}

The image quality factor is not merely a matter of whether the image is repeated or not, but also has a wide range of information and also has to maintain the protection method for the patient is the reception of the dose due to radiographic action. So it is necessary to monitor the patient's dose using the EI value. The factors that determine the EI value are the exposure factor and the thickness of the object or BMI (Body Mass Index). Exposure factors (kV and $\mathrm{mAs}$ ) are factors that have been commonly used as patient dose monitoring, where the tube voltage is a component that changes more often with a relatively constant tube current. The study used data on patients with Thoracic examination at the age of 20-65 years which were then categorized into BMI. The analysis was carried out on the EI value contained in the radiographic image. The results showed that BMI in the normal, Light Grade Fat (LGF), Heavy Grade Fat (HGF) categories, respectively, the EI values were 1562, 1679, and 1955 for the female sex, and 1266, 1600, and 1821 for the male gender. Significantly $(\mathrm{P} \leq 0.05)$ the EI value showed difference between female and male sexes.
\end{abstract}

International Journal of Life Sciences (C) 2021.

This is an open access article under the CC BY-NC-ND license (https://creativecommons.org/licenses/by-nc-nd/4.0/).

\section{Contents}

Abstract

1 Introduction.

2 Materials and Methods

3 Results and Discussions

4 Conclusion

\footnotetext{
a Physics Faculty of Mathematics and Natural Sciences, Udayana University, Denpasar, Indonesia

b Physics Faculty of Mathematics and Natural Sciences, Udayana University, Denpasar, Indonesia

c Physics Faculty of Mathematics and Natural Sciences, Udayana University, Denpasar, Indonesia
} 


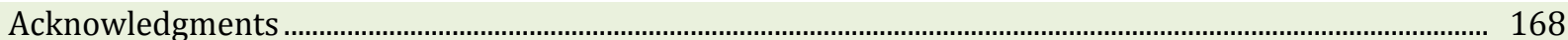

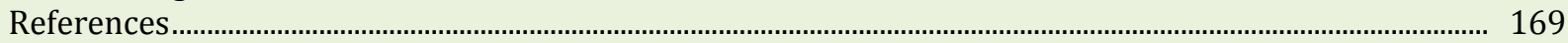

Biography of Authors ..................................................................................................................................... 170

\section{Introduction}

Establishing the diagnosis in some cases can be done by radiological examination. Radiological examination is an examination using X-rays to reveal the object being examined through the manufacture of radiographs that provide as much diagnostic information as possible (Bontrager \& Lampignano, 2013). The sophistication of digital imaging technology for diagnostics has been applied in imaging diagnostic services in hospitals. One of them is the use of Computed Radiography (CR). CR is a digital image acquisition and processing system for producing static radiographs. This system uses a standard X-ray tube and a generator but requires a special image receptor and a computerized image processing system consisting of an image receiver, an image reader, and a workstation (Susilo et al., 2012; Sutapa et al., 2018).

The function of digital image processing is to process data that has information suitable for computer processing and to improve image quality (Bushong, 2020). Image quality is a requirement to show the accuracy or representation of the patient's anatomy in the radiograph. An image that can clearly show the structure and soft tissue is said to have a good quality image. While the image is said to have poor quality if it contains images that are difficult to differentiate with the human eye. Optimal image quality with quantitative images helps accuracy in diagnosis, to avoid errors in diagnosis. According to Bontrager \& Lampignano (2013), states that the factors used to evaluate the quality of digital images are brightness, contrast, resolution, distortion, noise, and EI. One of the factors that determine the EI value is the exposure factor and the thickness of the object or BMI. So it is necessary to research monitoring patient doses using EI on BMI levels on chest X-ray examinations (Putra et al., 2019; Beydon et al., 1992).

\section{Materials and Methods}

The research location is in the Radiology Unit of the Kasih Ibu Hospital, Kedonganan, Badung. Meanwhile, data analysis was carried out at the Biophysics Laboratory, Bukit Jimbaran Campus. The tools used in this research are the X-ray device, collimator tool and beam alignment test tool, CR (Computer Radiography), lux meter, humidity meter, thermometer, and X-ray cassette 24 x $24 \mathrm{~cm}$ with imaging plate (Silva \& Yoshimura, 2014; Costa \& Pelegrino, 2014). The object of this research is adult patients with the appropriate provisions of the BMI level. Patients who will undergo the examination are categorized based on the BMI value, patients with a BMI above 27 are categorized as fat, while for skinny patients the BMI value is less than 18 . The X-ray tube voltage variable is set from $50,60,70,80$ and $90 \mathrm{kVp}$ with $20 \mathrm{mAs}$. From the measured EI value on the radiographic film for each voltage, the relationship between $\mathrm{kVp}$ and the BMI category can be determined, and then the patient dose can be determined according to the BMI level (Jones \& Nzekwu, 2006; Frankel et al., 1996). The research data were analyzed comparatively and statistically, by looking at and comparing the observations from the research conducted. The patient's weight data from the medical record adjusted to the BMI level can be determined by the EI value on the radiographic film. Furthermore, it is analyzed to determine the amount of patient dose according to bodyweight category. The statistical analysis used was ANOVA (Analysis of Variance). The ANOVA test results that were significantly different ( $\mathrm{P} \leq 0.05)$ showed a significant difference between the EI and BMI values (Erenstein et al., 2020; Drennan et al., 2019).

\section{Results and Discussions}

The research data from the examination of thorax patients consisted of 2 categories, namely female and male patients with an age range of 18-65 years as shown in Table 1. following,

Suandayani, N. K. T., Sutapa, G. N., \& Kasmawan, I. G. A. (2021). Patient dose monitoring using exposure index against body mass index level on chest X-ray examination. International Journal of Life Sciences, 5(3), 164-170.

https://doi.org/10.53730/ijls.v5n3.1722 
Table 1

Results of examination of thoracic patients against the exposure index

\begin{tabular}{|c|c|c|c|c|c|c|c|c|c|}
\hline \multirow{2}{*}{ No. } & \multirow{2}{*}{$\begin{array}{l}\text { No. } \\
\text { Registration }\end{array}$} & \multirow{2}{*}{ Gender } & \multirow{2}{*}{$\begin{array}{l}\text { Weight } \\
(\mathrm{kg})\end{array}$} & \multirow{2}{*}{$\begin{array}{l}\text { Height } \\
(\mathrm{cm})\end{array}$} & \multirow{2}{*}{$\begin{array}{l}\text { Age } \\
\text { (year) }\end{array}$} & \multicolumn{2}{|c|}{ Exposure } & \multirow{2}{*}{$\begin{array}{l}\text { Exposure } \\
\text { Type }\end{array}$} & \multirow{2}{*}{$\begin{array}{l}\text { Exposur } \\
\text { e Index }\end{array}$} \\
\hline & & & & & & $\mathrm{kV}$ & $\mathrm{mAs}$ & & \\
\hline 1 & 1776189 & $\mathrm{M}$ & 49 & 156 & 30 & 65 & 5 & Toraks PA & 1722 \\
\hline 2 & 1776325 & $\mathrm{~F}$ & 58 & 170 & 34 & 62 & 10 & Toraks PA & 1143 \\
\hline 3 & 1776334 & M & 53 & 163 & 33 & 57 & 5 & Toraks PA & 1446 \\
\hline 4 & 1778247 & $\mathrm{~F}$ & 57 & 168 & 32 & 70 & 5 & Toraks PA & 1592 \\
\hline 5 & 1778265 & M & 68 & 173 & 26 & 63 & 5 & Toraks PA & 1339 \\
\hline 6 & 1778340 & $\mathrm{~F}$ & 57 & 158 & 40 & 60 & 6 & Toraks PA & 1499 \\
\hline 7 & 1778357 & M & 70 & 180 & 34 & 66 & 6,3 & Toraks PA & 1540 \\
\hline 8 & 1778361 & $\mathrm{~F}$ & 55 & 168 & 31 & 60 & 6,5 & Toraks PA & 1250 \\
\hline 9 & 1781392 & M & 72 & 171 & 59 & 60 & 5 & Toraks AP & 1579 \\
\hline 10 & 1781075 & M & 69 & 168 & 31 & 66 & 5 & Toraks PA & 1450 \\
\hline 11 & 1781567 & M & 75 & 170 & 57 & 60 & 4 & Toraks AP & 1600 \\
\hline 12 & 1782458 & M & 72 & 175 & 28 & 63 & 9 & Toraks PA & 1042 \\
\hline 13 & 1782741 & $\mathrm{~F}$ & 60 & 163 & 30 & 55 & 6,3 & Toraks PA & 1419 \\
\hline 14 & 1783104 & $\mathrm{~F}$ & 76 & 169 & 55 & 66 & 6,4 & Toraks PA & 1540 \\
\hline 15 & 1783325 & $\mathrm{~F}$ & 80 & 167 & 65 & 73 & 6,4 & Toraks AP & 1898 \\
\hline 16 & 1783556 & M & 62 & 157 & 21 & 60 & 6 & Toraks PA & 1402 \\
\hline 17 & 1784356 & M & 68 & 155 & 55 & 73 & 10 & Toraks PA & 1955 \\
\hline 18 & 1784455 & $\mathrm{~F}$ & 76 & 177 & 61 & 66 & 8 & Toraks PA & 1608 \\
\hline 19 & 1784629 & $\mathrm{~F}$ & 67 & 169 & 29 & 60 & 4 & Toraks PA & 1175 \\
\hline 20 & 1784599 & $\mathrm{~F}$ & 82 & 170 & 47 & 70 & 10 & Toraks PA & 1834 \\
\hline 21 & 1785119 & $\mathrm{~F}$ & 77 & 172 & 38 & 63 & 8 & Toraks PA & 1601 \\
\hline 22 & 1785462 & $\mathrm{~F}$ & 68 & 168 & 20 & 63 & 6,4 & Toraks PA & 1407 \\
\hline 23 & 1785962 & $\mathrm{~F}$ & 67 & 167 & 37 & 63 & 4 & Toraks PA & 1254 \\
\hline 24 & 1786141 & $\mathrm{~F}$ & 70 & 170 & 37 & 66 & 12,5 & Toraks PA & 1534 \\
\hline 25 & 1786028 & $\mathrm{~F}$ & 83 & 172 & 54 & 70 & 6 & Toraks AP & 1743 \\
\hline 26 & 1786422 & M & 61 & 153 & 60 & 55 & 4 & Toraks AP & 1534 \\
\hline 27 & 1786499 & M & 50 & 157 & 50 & 60 & 6,4 & Toraks PA & 1009 \\
\hline 28 & 1786196 & $\mathrm{~F}$ & 69 & 169 & 56 & 66 & 4 & Toraks AP & 1388 \\
\hline 29 & 1783225 & M & 57 & 160 & 25 & 60 & 6 & Toraks PA & 1402 \\
\hline 30 & 1784456 & M & 68 & 159 & 55 & 73 & 10 & Toraks PA & 1955 \\
\hline
\end{tabular}

Next, the BMI category is determined for gender and the average value is taken against the EI value, as shown in Table 2. Below

Table 2

The average value of EI against the BMI category

\begin{tabular}{llll}
\hline BMI Category Gender & Normal & Light Grade Fat (LGF) & Heavy Grade Fat (HGF) \\
\hline Famale & 1821 & 1600 & 1266 \\
Man & 1955 & 1671 & 1562 \\
\hline
\end{tabular}




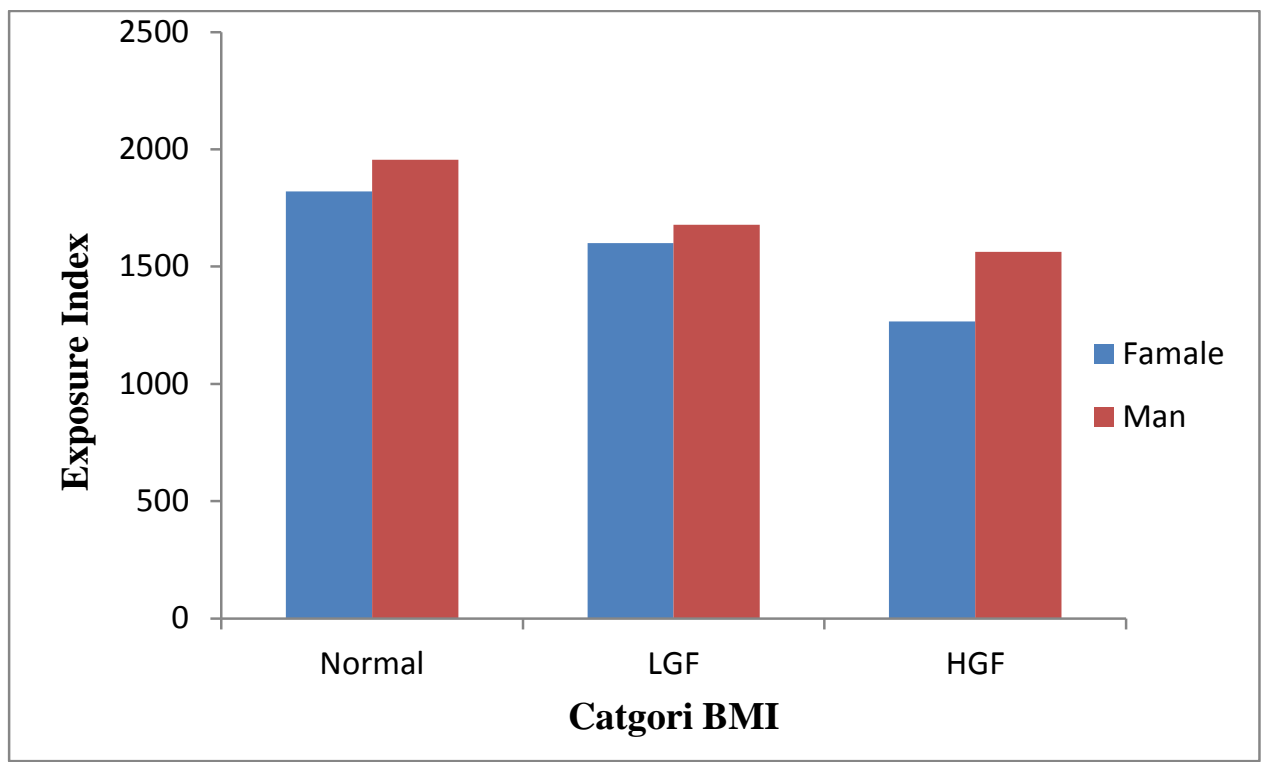

Figure 1. Graph of the relationship between BMI and EI value.

The results of the study as shown in Figure 1, in general, the IE value decreased from the normal BMI, LGF, and HGF categories, for both female and male gender (Adler et al., 1992; Rosidah et al., 2020). It can be understood that EI is a measure of the amount of radiation exposure received by the image receptor (IR). Radiologists and radiographers use the EI standard as the optimal standard of exposure accepted by IR. The EI values listed in the CR have varying ranges. In Carestream/kodak CR, the acceptable IE value is in the range of 1000-2000 (Mothiram et al., 2013). The results of the study have an EI value in the range of 1266 to 1955, which is a value that has met the exposure dose to produce good image quality. Based on the research of Rochmayanti et al. (2019), to get an optimal image on chest examination, an EI value of 1725 is needed. Thus, the LGF and HGF categories still meet the optimal EI value, so the image quality can still be read clearly (Gill et al., 2018; Putra et al., 2021).

Although the EI value is determined by the exposure factor and the thickness of the object or BMI, in this study the EI value was also influenced by gender. Women at all BMI levels had higher EI scores than men. Statistically also showed a significant difference $(\mathrm{P} \leq 0.05)$ between female and male EI scores (Renehan et al., 2008; Iseki et al., 2004). It can be understood that in general the posture/shape of the female body is anatomically thicker than the male body, so the absorption of radiation doses will occur more in the female patient's body. So the value of EI received by the IR will be smaller. This condition also supports research conducted by Arifiansyah (2018), which states that a person's weight and height will affect the amount of EI value received by the IR (Indonesia, 2009; Strauss \& Rae, 2012).

\section{Conclusion}

The IE value is a measure of the amount of radiation exposure received by the image receptor (IR). The results showed that the IE values for BMI in the normal, LGF, and HGF categories were 1562, 1679, and 1955 for males, and 1266, 1600, and 1821 for females, respectively. Significantly $(P \leq 0.05)$ the EI value showed the difference between male and female sexes.

Conflict of interest statement

The authors declared that they have no competing interests.

Suandayani, N. K. T., Sutapa, G. N., \& Kasmawan, I. G. A. (2021). Patient dose monitoring using exposure index against body mass index level on chest X-ray examination. International Journal of Life Sciences, 5(3), 164-170. 
Statement of authorship

The authors have a responsibility for the conception and design of the study. The authors have approved the final article.

Acknowledgments

Acknowledgments to Udayana University for funding the implementation of this research through the Unud DIPA PNBP in the fiscal year 2020 following the Letter of Appointment for the Study Program Leading Research (PUPS). 


\section{References}

Adler, A., Carlton, R., \& Wold, B. (1992). A comparison of student radiographic reject rates. Radiologic technology, 64(1), 26-32.

Arifiansyah, A. (2018). Penentuan Keluaran Radiasi terhadap Pasien Berdasarkan Indeks Massa Tubuh pada Pesawat X Ray.

Beydon, L., Saada, M., Liu, N., Becquemin, J. P., Harf, A., Bonnet, F., ... \& Rahmouni, A. (1992). Can portable chest x-ray examination accurately diagnose lung consolidation after major abdominal surgery?: a comparison with computed tomography scan. Chest, 102(6), 1697-1703. https://doi.org/10.1378/chest.102.6.1697

Bontrager, K. L., \& Lampignano, J. (2013). Textbook of radiographic positioning and related Anatomy-E-Book. Elsevier Health Sciences.

Bushong, S. C. (2020). Radiologic Science for Technologists E-Book: Physics, Biology, and Protection. Elsevier Health Sciences.

Costa, A. M., \& Pelegrino, M. S. (2014). Evaluation of entrance surface air kerma from exposure index in computed radiography. Radiation Physics and Chemistry, 104, 198-200. https://doi.org/10.1016/j.radphyschem.2014.05.005

Drennan, P. G., Begg, E. J., Gardiner, S. J., Kirkpatrick, C. M., \& Chambers, S. T. (2019). The dosing and monitoring of vancomycin: what is the best way forward?. International journal of antimicrobial agents, 53(4), 401-407. https://doi.org/10.1016/j.ijantimicag.2018.12.014

Erenstein, H. G., Browne, D., Curtin, S., Dwyer, R. S., Higgins, R. N., Hommel, S. F., ... \& England, A. (2020). The validity and reliability of the exposure index as a metric for estimating the radiation dose to the patient. Radiography, 26, S94-S99. https://doi.org/10.1016/j.radi.2020.03.012

Frankel, S., Elwood, P., Smith, G. D., Sweetnam, P., \& Yarnell, J. (1996). Birthweight, body-mass index in middle age, and incident coronary heart disease. The Lancet, 348(9040), 1478-1480. https://doi.org/10.1016/S0140-6736(96)03482-4

Gill, H. S., Elshahat, B., Kokil, A., Li, L., Mosurkal, R., Zygmanski, P., ... \& Kumar, J. (2018). Flexible perovskite based X-ray detectors for dose monitoring in medical imaging applications. Physics in Medicine, 5, 20-23. https://doi.org/10.1016/j.phmed.2018.04.001

Indonesia, R. (2009). Keputusan Menteri Kesehatan Republik Indonesia.

Iseki, K., Ikemiya, Y., Kinjo, K., Inoue, T., Iseki, C., \& Takishita, S. (2004). Body mass index and the risk of development of end-stage renal disease in a screened cohort. Kidney international, 65(5), 1870-1876. https://doi.org/10.1111/j.1523-1755.2004.00582.x

Jones, R. L., \& Nzekwu, M. M. U. (2006). The effects of body mass index on lung volumes. Chest, 130(3), 827833. https://doi.org/10.1378/chest.130.3.827

Mothiram, U., Brennan, P. C., Robinson, J., Lewis, S. J., \& Moran, B. (2013). Retrospective evaluation of exposure index (EI) values from plain radiographs reveals important considerations for quality improvement. Journal of medical radiation sciences, 60(4), 115-122.

Putra, I. K., Ratnawati, G. A. A., \& Sutapa, G. N. (2021). General radiographic patient dose monitoring using conformity test data. International Research Journal of Engineering, IT \& Scientific Research, 7(6), 219-224. https://doi.org/10.21744/irjeis.v7n6.1953

Putra, I. K., Suryatika, I. B. M., Ratnawati, I. G. A. A., \& Sutapa, G. N. (2019). Radiation protection x-ray in the diagnostic radiology unit kasih ibu kedonganan hospital. International Research Journal of Engineering, IT \& Scientific Research, 5(6), 18-24. https://doi.org/10.21744/irjeis.v5n6.786

Renehan, A. G., Tyson, M., Egger, M., Heller, R. F., \& Zwahlen, M. (2008). Body-mass index and incidence of cancer: a systematic review and meta-analysis of prospective observational studies. The lancet, 371(9612), 569-578. https://doi.org/10.1016/S0140-6736(08)60269-X

Rochmayanti, D., Wibowo, G. M., \& Setiawan, A. N. (2019, February). Implementation of exposure index for optimize image quality and patient dose estimation with computed radiography (a clinical study of adult posteroanterior chest and anteroposterior abdomen radiography). In Journal of Physics: Conference Series (Vol. 1153, No. 1, p. 012032). IOP Publishing.

Rosidah, S., Soewondo, A., \& Adi, M. S. (2020). Optimasi Kualitas Citra Radiografi Abdomen Berdasarkan Body Mass Index dan Tegangan Tabung pada Computed Radiography.Jurnal Epidemiologi Kesehatan Komunitas, 5(1), 23-31.

Suandayani, N. K. T., Sutapa, G. N., \& Kasmawan, I. G. A. (2021). Patient dose monitoring using exposure index against body mass index level on chest X-ray examination. International Journal of Life Sciences, 5(3), 164-170.

https://doi.org/10.53730/ijls.v5n3.1722 
Silva, T. R., \& Yoshimura, E. M. (2014). Patient dose, gray level and exposure index with a computed radiography system. Radiation Physics and Chemistry, 95, 271-273. https://doi.org/10.1016/j.radphyschem.2012.12.043

Strauss, L. J., \& Rae, W. I. (2012). Image quality dependence on image processing software in computed radiography. SA Journal of Radiology, 16(2).

Susilo, S., Sunarno, S., Setiowati, E., \& Lestari, L. (2012). Aplikasi alat radiografi digital dalam pengembangan layanan foto rontgen. Jurnal MIPA Unnes, 35(2), 114115.

Sutapa, G. N., Yuliara, I. M., \& Ratini, N. N. (2018). Verification of dosage and radiation delivery time breast cancer (Mammae Ca) with ISIS TPS. International journal of health sciences, 2(2), 78-88.

\section{Biography of Authors}

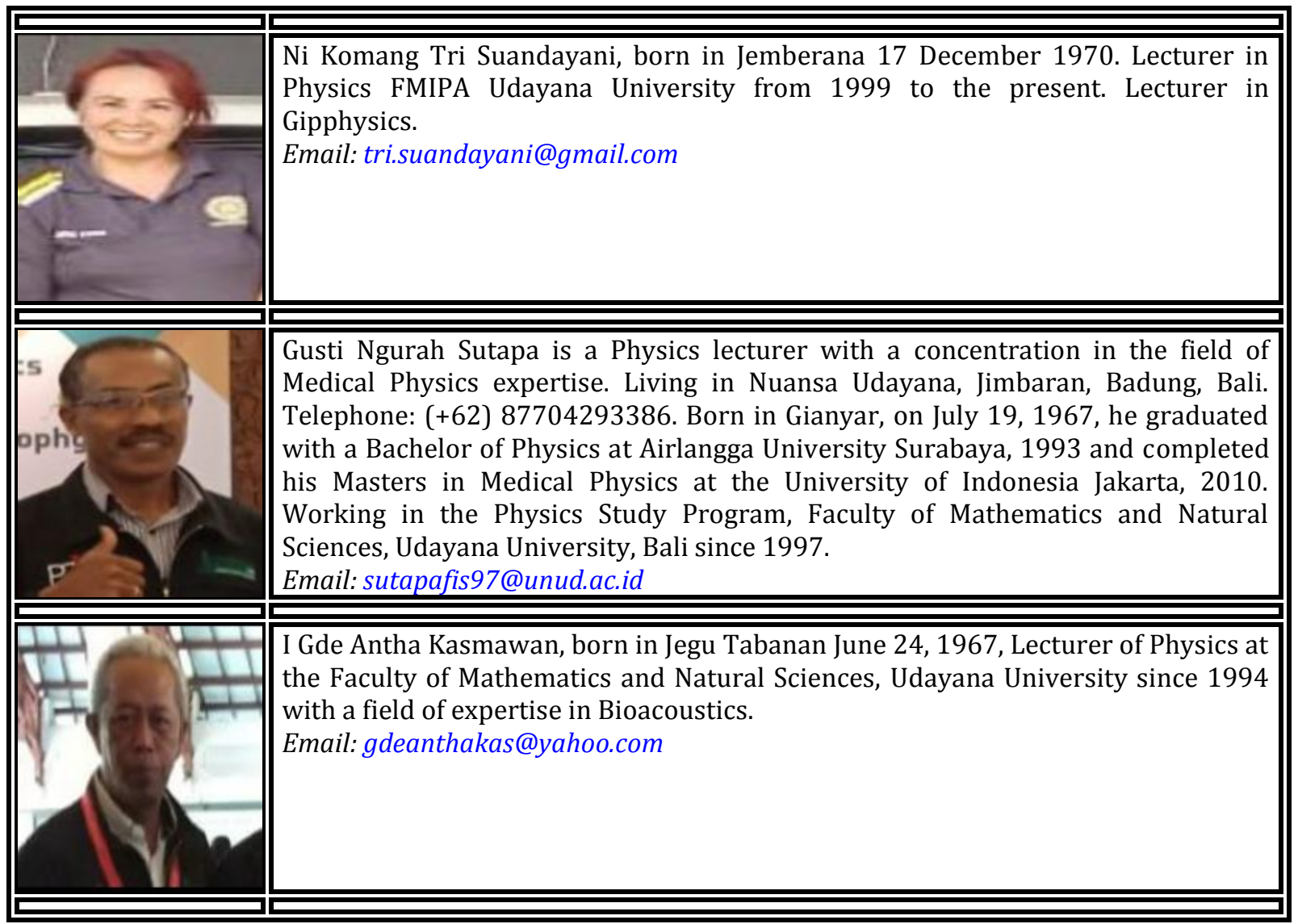

